\title{
Tensile strength of the rachilla in spikelets of Polish Festulolium braunii cultivars
}

\author{
B. GOLIŃSKA, and P. GOLIŃSKI* \\ Department of Grassland and Natural Landscape Sciences, Poznan University of Life Sciences, \\ PL-60632 Poznań, Poland
}

\begin{abstract}
The aim of this study was to evaluate the tensile strength of the rachilla in spikelets of Polish cultivars of Festulolium braunii (K. Rich.) A. Camus during seed development and maturation. The investigations were carried out in 2009 - 2010 at the Plant Breeding, Szelejewo, Poland. The inflorescences were randomly harvested in June - July from plant collection in maintenance breeding of three Polish cultivars (Agula, Felopa, and Sulino). Using a specifically developed testing machine, tensile strength of the rachilla of individual spikelets were determined. Regardless of the $F$. braunii cultivar, the tensile strength of the rachilla decreased through consecutive growth stages. The highest tensile strength of the rachilla was observed during the phase of kernel watery ripe stage $(\mathrm{BBCH} 71)$ - it ranged from $510.1 \mathrm{mN}$ in 'Agula' to $592.0 \mathrm{mN}$ in 'Felopa'. At the fully ripe phase (BBCH 89), the value of this trait ranged from $19.2 \mathrm{mN}$ in 'Agula' to $45.0 \mathrm{mN}$ in 'Felopa'. It was also observed that in all tested cultivars of $F$. braunii, the spikelets located in the lower part of the spike were characterised by the highest tensile strength of the rachilla, whereas those in the upper part were characterised by the lowest values of this trait. This means that the caryopses in the spikelets located at the lower part of the inflorescence were less susceptible to shedding. Seed shedding the Polish F. braunii cultivars, especially 'Agula' and 'Sulino', may start as early dough and soft dough phases. By contrast, seed shedding 'Felopa' is moved to the later phases of seed maturation.
\end{abstract}

Additional key words: growth stage, seed development, seed maturation, seed shedding.

\section{Introduction}

Festulolium braunii cultivars, obtained from crossing autotetraploid forms of meadow fescue and Italian ryegrass in combinations Festuca pratensis $(2 \mathrm{n}=4 \mathrm{x}=28) \times$ Lolium multiflorum $(2 \mathrm{n}=4 \mathrm{x}=28)$, are valuable components of seed mixtures designed for ley farming, and can even be used for renovation of permanent grassland (Kryszak et al. 2002, Opitz von Boberfeld and Banzhaf 2006, Wolski et al. 2006, Olszewska 2008, Ghesquière et al. 2010, Černoch and Groenbaek 2015, Wyss and Frick 2019). The high nutritional value and high dry matter yield potential of these cultivars provide an opportunity to reduce the costs of milk and beef production.

Due to these beneficial traits of $F$. braunii the demand for seed of registered cultivars is increasing. Therefore, an important research issue is to assess the seed potential of Festulolium, both in creating new cultivars (Baert et al. 2019) and their reproduction (Humphreys and Marshall 2000). In the evaluation of initial material used for cross-breeding, one of the most important biological traits is fertility, the level of which in hybrid forms is decisive for the reproduction of new breeding material (Zwierzykowski et al. 1998). In turn, the crucial issue to improve the profitability of seed plantations of already existing $F$. braunii cultivars is to increase the seed yield (Ghesquière et al. 2010, Goliński et al. 2010).

The biological traits that require quantification for increasing the efficiency of grass seed plantations and the selection of shedding-resistant forms is the seed retention strength in spikelets and tensile strength of the rachilla (Coolbear et al. 1997). There are complex physical and physiological changes in the elements of the inflorescence structure during the maturing process of grasses (Sexton and Roberts 1982). In many grass species, they lead to seed shedding, which often limits breeding achievements, due to reduced seed yield of their cultivars (Lorenzetti 1993, Humphreys and Marshall 2000). F. braunii belongs to the group of such species. Therefore, it becomes necessary to evaluate this phenomenon by means of precise measuring

Submitted 11 May 2020, last revision 17 June 2020, accepted 13 July 2020.

Abbreviation: $\mathrm{BBCH}$ - Biologische Bundesanstalt, Bundessortenamt und Chemische Industrie.

Acknowledgements: This study was funded by the Ministry of Agriculture and Rural Development as a subsidy for basic research for biological progress in crop production (grant No. HOR hn $-078 \mathrm{dec} / 11 / 10$ ). The authors are grateful to Dr. Gregory Taff for revision of the English writing.

* Corresponding author; e-mail: pgolinsk@up.poznan.pl 
devices monitoring the process of seed shedding, including the tensile strength of the rachilla in spikelets. This will allow assessment of the diversity of this biological trait in $F$. braunii genotypes. Research results in this field can be helpful for production of cultivars, in particular optimizing seed harvesting technology.

The objective of this study was to evaluate the tensile strength of the rachilla in spikelets of Polish cultivars of $F$. braunii in subsequent growth stages during seed development and seed maturation.

\section{Materials and methods}

The study was conducted in 2009-2010 on plant material obtained from Polish cultivars of Festulolium braunii (K. Richter) A. Camus at Plant Breeding, Szelejewo, Poland. The experimental material was a plant collection (51 $\left.51^{\prime} 30^{\prime \prime} \mathrm{N}, 1^{\circ} 09^{\prime} 34^{\prime \prime} \mathrm{E}\right)$ used in maintenance breeding of three Polish cultivars: Agula, Felopa, and Sulino (loloid type) of F. braunii, currently maintained by Danko Plant Breeding. These cultivars have been registered on the Polish National List since 1998 ('Felopa' and 'Sulino') and 2002 ('Agula') and are included in the EU common catalogue of cultivars of agricultural plant species. The clones of cultivars were planted in 2008 on Cambisols soil ( $\mathrm{pH}_{\mathrm{KCl}}-5.8$, humus - $1.04 \%$, and $\mathrm{P}-0.219, \mathrm{~K}-0.109$, and $\left.\mathrm{Mg}-0.074 \mathrm{mg} \mathrm{g}^{-1}\right)$. The weather conditions during the period of vegetative growth and maturation of generative shoots in 2009 and 2010 were similar to multiyear averages. Only in 2009 higher rainfall (156 mm) occurred in June, which, in combination with relatively low air temperatures (daily average $10.4{ }^{\circ} \mathrm{C}$ ), delayed the beginning of the seed maturation process. However in 2010, high rainfall was recorded in May $(155 \mathrm{~mm})$, and rainfall lower than multiyear averages was recorded in June $(33 \mathrm{~mm})$ and July $(52 \mathrm{~mm})$. The analytical material consisted of 30 inflorescences of each cultivar randomly collected from the plant collection during June-July in the subsequent eight growth stages of seed development and maturation (Table 1) according to the Biologische Bundesanstalt, Bundessortenamt und Chemische Industrie scale (Meier 2001). F. braunii ears were collected in the first (2009) and second (2010) year of seed yield.

The tensile strength of the rachilla in individual spikelets of Festulolium braunii inflorescences was tested with a prototype machine for measuring tensile strength of biological material. The construction of the machine was based on components manufactured by Höttinger Baldwin Messtechnik(Darmstadt, Germany), i.e., strain gauges with appropriate nominal ranges, special measuring amplifiers with analogue/digital processing with a resolution of 24 bits. Mechanically compensated sensors are largely independent of not centric power transmission and they guarantee high accuracy $(0.02 \%)$. Due to digital filtration the amplifier guarantees an accuracy of $0.01 \%$. The whole machine was connected to a digital recorder system using the MS Windows operating system. A platform with the latest generation of the $P W 4 M C 3$ sensor was used to measure the tensile strength of the rachilla in spikelets. The breakage of the rachilla occurred in the abscission layer, which forms between the individual florets, as a result of manual force along the direction of spikelet axis by means of a special handle and tweezers (Goliński 2009).

The tensile strength of the rachilla in individual spikelets was tested in 30 replicates for each of the cultivars. The results for individual cultivars were given as the average values from two years of research for subsequent growth stages. Due to different sizes of $F$. braunii inflorescences, special attention was given to the 12 spikelets growing on the spike axis, counting from the bottom of the inflorescence, according to the methodology described by Golińska (2009). The zones of position of the spikelets in the inflorescence were accounted for (lower - spikelets 1 to 4 , middle - spikelets 5 to 8 , upper - spikelets 9 to 12 ). The results of measurement of the tensile strength of the rachilla in individual inflorescence zones were given for specific cultivars in the first and second year of seed yield.

The data were analysed using ANOVA. The main effects on the cultivar were tested with $F$-tests. The means were separated by the least squared difference (LSD) at a significance level $\alpha=0.05$. The standard deviation and coefficient of variation were also calculated. As far as the position of the spikelet in the inflorescence is concerned, the average values at individual growth stages were used to calculate trends of changes in the tensile strength of the rachilla by means of linear regression.

\section{Results}

The results showed that the tensile strength of the rachilla decreased in all the $F$. braunii cultivars from phase $\mathrm{BBCH}$ 71 to $\mathrm{BBCH} 89$ (Table 1). At the growth stage of kernels watery ripe, 'Felopa' was characterised by a significantly greater force necessary to break the rachilla. At the subsequent growth stages (BBCH 73 - 77) the differences between the cultivars were not significant. There were noticeable differences between the cultivars at the end of seed maturation, from phase $\mathrm{BBCH} 83$ to $\mathrm{BBCH} 89$. At the early dough growth stage, 'Felopa' exhibited a significantly higher tensile strength of the rachilla, by $33 \%$ compared to 'Sulino' and $42 \%$ relative to 'Agula'. This difference was also observed at the subsequent growth stages. At the soft dough phase all the cultivars differed significantly in the tensile strength of the rachilla. The highest tensile strength of the rachilla was observed in 'Felopa' $(180 \mathrm{mN})$, whereas the lowest tensile strength of the rachilla was measured in 'Agula' (122 mN). These differences between the cultivars were also observed at the subsequent final stage of seed maturation. The higher tensile strength of the rachilla of 'Felopa' showed that this cultivar was characterised by greater resistance to caryopses shedding than other cultivars. By contrast, 'Agula' was characterised by the highest susceptibility to seed shedding, because the tensile strength of its rachilla was the lowest, especially at the last stages of seed maturation - the hard dough and fully ripe stages.

It is noteworthy that the tests of the tensile strength of the rachilla revealed considerable variability, which 
Table 1. Tensile strength $[\mathrm{mN}]$ of the rachilla of Polish Festulolium braunii cultivars in subsequent growth stages during seed development and seed maturation.

\begin{tabular}{|c|c|c|c|c|}
\hline Growth stage (BBCH scale) & Cultivar & Mean & SD & Variation coefficient $[\%]$ \\
\hline \multirow{3}{*}{ Kernels watery ripe (71) } & Agula & 510.1 & 169.3 & 33.2 \\
\hline & Felopa & 592.0 & 110.9 & 18.7 \\
\hline & Sulino & 519.9 & 154.8 & 29.8 \\
\hline $\mathrm{LSD}_{0.05}$ & & 45.6 & - & - \\
\hline \multirow[t]{3}{*}{ Early milk (73) } & Agula & 412.4 & 112.4 & 27.3 \\
\hline & Felopa & 434.0 & 86.5 & 19.9 \\
\hline & Sulino & 411.7 & 85.1 & 20.7 \\
\hline $\mathrm{LSD}_{0.05}$ & & ns & - & - \\
\hline \multirow{3}{*}{ Medium milk (75) } & Agula & 369.8 & 116.1 & 31.4 \\
\hline & Felopa & 382.8 & 112.9 & 29.5 \\
\hline & Sulino & 372.5 & 101.4 & 27.2 \\
\hline $\mathrm{LSD}_{0.05}$ & & ns & - & - \\
\hline \multirow{3}{*}{ Late milk (77) } & Agula & 230.7 & 70.0 & 30.4 \\
\hline & Felopa & 240.9 & 75.7 & 31.4 \\
\hline & Sulino & 257.1 & 74.1 & 28.8 \\
\hline $\mathrm{LSD}_{0.05}$ & & ns & - & - \\
\hline \multirow{3}{*}{ Early dough (83) } & Agula & 160.7 & 30.9 & 19.3 \\
\hline & Felopa & 227.4 & 73.6 & 32.4 \\
\hline & Sulino & 171.1 & 39.8 & 23.3 \\
\hline $\mathrm{LSD}_{0.05}$ & & 18.19 & - & - \\
\hline \multirow{3}{*}{ Soft dough (85) } & Agula & 122.0 & 39.0 & 31.9 \\
\hline & Felopa & 180.0 & 58.0 & 32.2 \\
\hline & Sulino & 144.0 & 44.9 & 31.2 \\
\hline $\mathrm{LSD}_{0.05}$ & & 15.4 & - & - \\
\hline \multirow[t]{3}{*}{ Hard dough (87) } & Agula & 43.1 & 13.1 & 30.5 \\
\hline & Felopa & 110.7 & 24.7 & 22.3 \\
\hline & Sulino & 89.1 & 20.9 & 23.5 \\
\hline $\mathrm{LSD}_{0.05}$ & & 6.4 & - & - \\
\hline \multirow[t]{3}{*}{ Fully ripe (89) } & Agula & 19.2 & 5.8 & 30.4 \\
\hline & Felopa & 45.0 & 12.5 & 27.7 \\
\hline & Sulino & 36.3 & 11.1 & 30.6 \\
\hline $\mathrm{LSD}_{0.05}$ & & 2.9 & - & - \\
\hline
\end{tabular}

was reflected by the values of standard deviation and coefficient of variation. This means that despite the careful collection of inflorescences at individual growth stages, there was high variation in the tensile strength of the rachilla. The value of this trait is influenced not only by the phase of plant development but also by other factors, e.g., the weather conditions during the maturity of generative shoots. In addition, the research results cover two years of the seed yielding of $F$. braunii cultivars, which differed in weather conditions during plant maturation.

Analysing the differences in the tensile strength of the rachilla of the $F$. braunii cultivars in more detail, the position of the spikelets on the inflorescence axis in the subsequent years of seed yield were taken into account. The changes in the tensile strength of the rachilla during the seed development and maturation of 'Agula' in the first (Fig. 1A) and second year of yield (Fig. $1 B$ ) show that the rachilla of the spikelets located in the upper part of the inflorescence was characterised by smaller tensile strength than in the spikelets located in the middle and lower zones. The linear regression showed that as the seed maturation phase progressed, there were fewer differences in the tensile strength of the rachilla between the spikelets, depending on their position on the spike axis. Nevertheless, in both years at each growth stage the lowest value of this trait was measured in the upper spikelets. Although at the early stage of seed development there were noticeable differences in the middle and lower spikelets, they were practically nonexistent at the final stage of seed maturation, i.e., at phases $\mathrm{BBCH} 87$ and $\mathrm{BBCH} 89$.

The changes in the tensile strength of the rachilla of 'Felopa' at individual growth stages were similar to those of 'Agula'. The regression lines showed lower values of this trait in the upper spikelets both in the first (Fig. 2A) and second year (Fig. $2 B$ ) of seed yield. In the first year the differences between the spikelets in the tensile strength of the rachilla tended to decrease as the seed maturation period progressed. In the second year these differences 


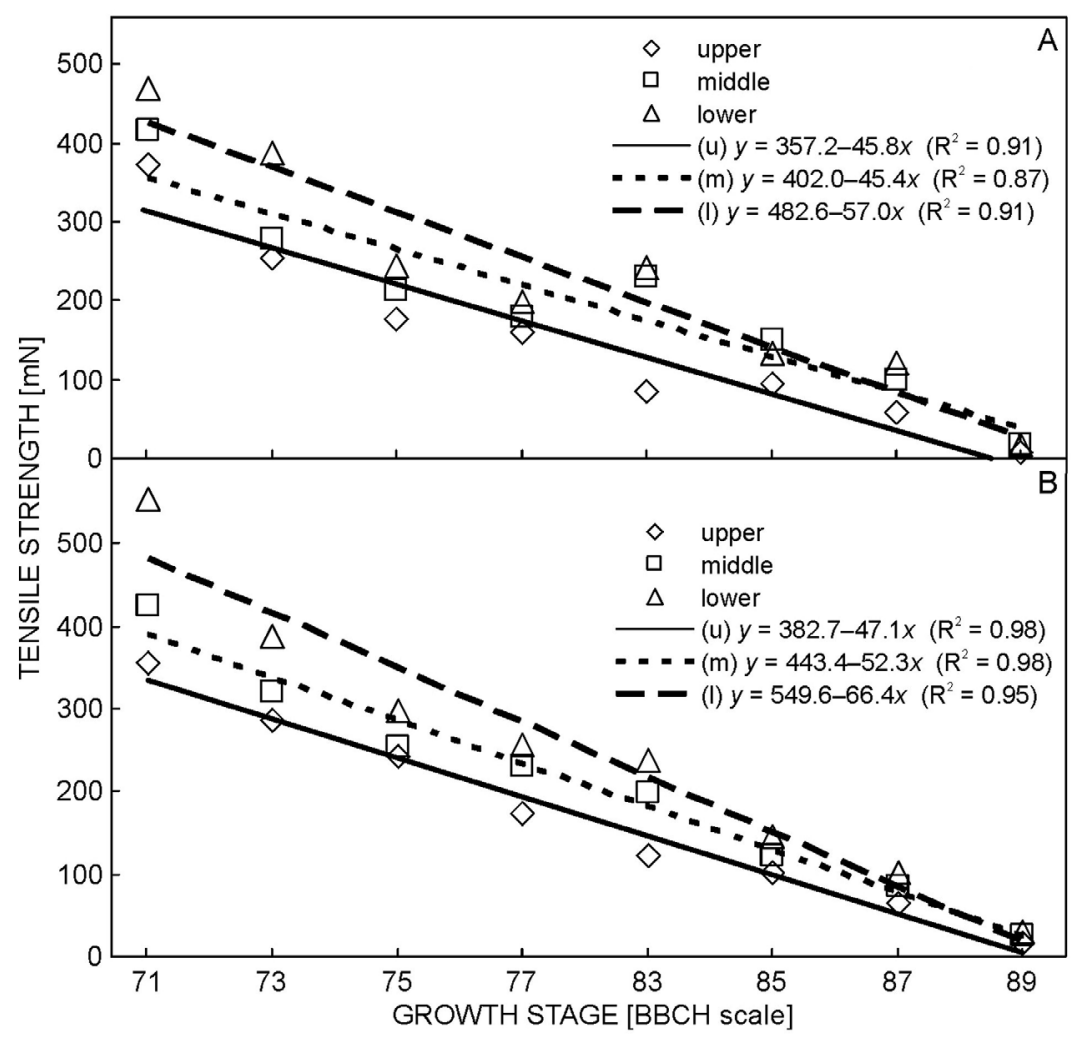

Fig. 1. Tensile strength of the rachilla of cv. Agula in subsequent growth stages during seed development and seed maturation in the first $(A)$ and second $(B)$ year of seed yield in regard to position of the spikelets on the inflorescence axis.

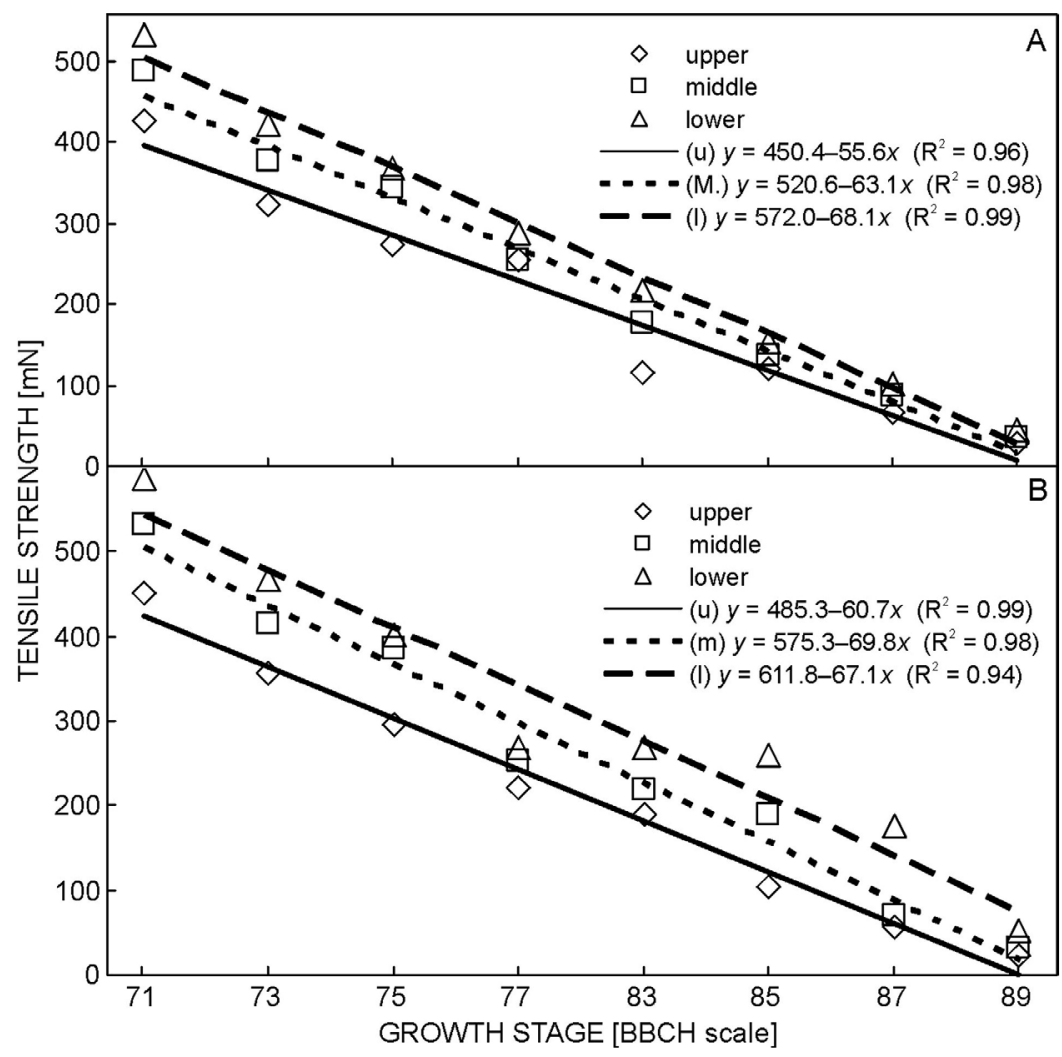

Fig. 2. Tensile strength of the rachilla of cv. Felopa in subsequent growth stages during seed development and seed maturation in the first $(A)$ and second $(B)$ year of seed yield in regard to position of the spikelets on the inflorescence axis. 
were still observed between the upper and lower spikelets at all the phases. The value of this trait in the middle spikelets decreased faster at the subsequent growth stages. As a consequence, at the final stages of seed maturation the differences between the middle and upper spikelets were minimal.

The tensile strength of the rachilla of 'Sulino' at the subsequent growth stages exhibited significant differences between the years of seed yield (Fig. 3A,B). In the first year the values of this trait at the early stage of seed development were higher than in the second year of the research, especially in the upper and middle spikelets. Then, as the development progressed, the tensile strength of the rachilla decreased in all the spikelets according to the regression lines. The tensile strength of the rachilla in 'Sulino' was much higher in the lower spikelets, which suggests their high resistance to seed shedding.

\section{Discussion}

Despite the use of optimal agrotechnical procedures in grass seed plantations, the reproduction of cultivars may fail due to seed shedding, which may be compounded by the weather conditions, such as strong wind and heavy rainfall during the advanced stage of seed maturity in a field (Rolston and Chynoweth 2010). Shedding causes a loss of 15 - $60 \%$ seed yield in grass plantations
(Falkowski et al. 1996). F. braunii is a grass species that develops multi-flower spikelets in inflorescences. The shedding of individual caryopses or fragments of the spikelet occurs due to breakage of the rachilla, which is caused by mechanical forces and/or complex physical and physiological processes. According to Elgersma et al. (1988), seed shedding is the result of stresses occurring in the thin-walled layer of cells, which cause the abscission layer to crack. Sexton and Roberts (1982) reported, that shedding depends on the enzymatic activity of cellulase and polygalacturonase, which cause decomposition of the cell wall. As given by González-Carranza et al. (1998), there are three phases of the process of the breakage of the rachilla. Initially, one or more morphogenetic signals cause cell differentiation in the abscission layer. Stress, the presence of abscisic acid, polyamines, and the ageing of cells cause the production of ethylene, which promotes the expression of genes responsible for the production of polygalacturonase, cellulase, and peroxidase. These enzymes degrade the cell wall and cause division of the abscission layer. The process appears to be subject to hormonal control in that high content of auxin inhibit, while abscisic acid and ethylene promote abscission (Boelt and Studer 2010). During seed maturation physical and physiological changes occur in various elements of the inflorescence (Sexton and Roberts 1982). They affect the tensile strength of the rachilla (Coolbear et al. 1997). Therefore, research on the effects of these processes in

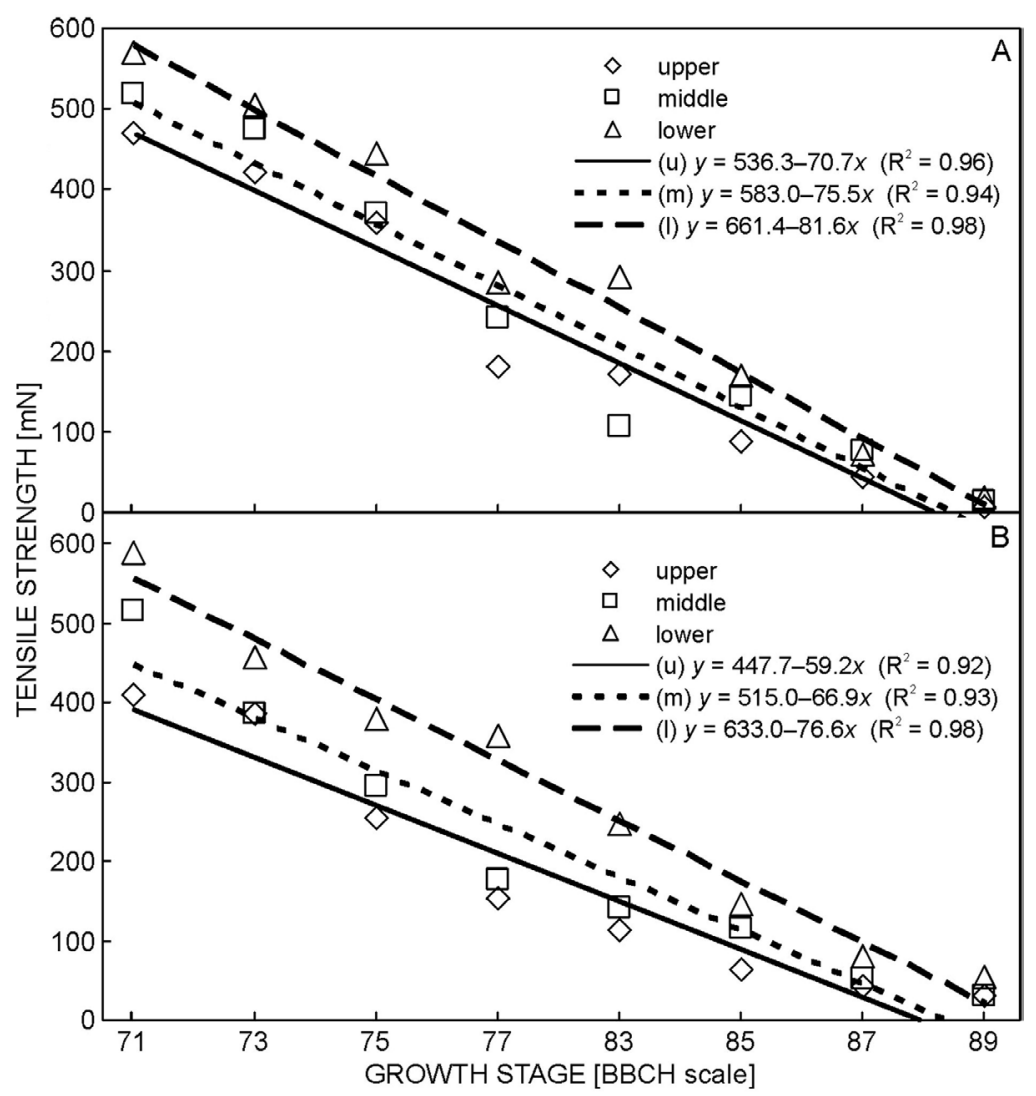

Fig. 3. Tensile strength of the rachilla of cv. Sulino in subsequent growth stages during seed development and seed maturation in the first $(A)$ and second $(B)$ year of seed yield in regard to position of the spikelets on the inflorescence axis. 
the form of tests of the tensile strength of the rachilla in various $F$. braunii genotypes helps to explain the seed shedding process, which may occur at early stages of seed maturation.

In an earlier study on the tensile strength of the rachilla of L. multiflorum the force necessary to break the rachilla tended to decrease as the period of maturity passed and subsequent growth stages progressed (Golińska 2009). Similar results were observed in this study. Regardless of the $F$. braunii cultivar, the tensile strength of the rachilla decreased as consecutive growth stages began. The highest tensile strength of the rachilla was observed at the phase of kernels watery ripe $(\mathrm{BBCH} 71)$ and decreased at the fully ripe phase (BBCH 89). Finding differences in the tensile strength of the rachilla enables identification of the genotypes that are resistant to caryopses shedding, which contributes to progress in breeding (Goliński 2009). Seeds are harvested at growth stages BBCH $83-87$, which involve mowing and threshing. In our study in these seed maturity phases, 'Felopa' was characterised by the highest tensile strength of the rachilla. It was followed by 'Sulino' and 'Agula' . These results imply differences in seed shedding of $F$. braunii cultivars, indicating that 'Felopa' is the most resistant to seed loss. Differences between cultivars were also observed in the study conducted by Goliński (2009).

The tensile strength of the rachilla in the spikelets of $F$. braunii cultivars was characterised by high variability. It was reflected by the values of standard deviation and variation coefficient. Golińska (2009) made similar observations in a study on L. multiflorum, where the variation coefficient for the tensile strength of the rachilla of different genotypes of this species at the soft dough phase amounted to $60 \%$.

The tensile strength of the rachilla of individual spikelets in the inflorescence of $F$. braunii cultivars differed depending on their position on the inflorescence axis. Regardless of the cultivar, the spikelets located in the lower part of the spike were characterised by the highest tensile strength of the rachilla, whereas those in the upper part were characterised by the lowest values of this trait. Apart from that, the difference between the tensile strength of the rachilla in the upper, middle, and lower spikelets tended to decrease as the phase of seed development and maturation progressed. Golińska (2009) also observed that the tensile strength of the rachilla of $L$. multiflorum tended to decrease depending on its position on the inflorescence axis. The author found that the caryopses in the spikelets located in the middle and upper part of the spike were more susceptible to shedding caused by mechanical factors such as wind and rain. This study resulted in a similar conclusion. The seed shedding of the Polish F. braunii cultivars, especially 'Agula' and 'Sulino', may start as the early dough and soft dough phases. By contrast, the seed shedding of the 'Felopa' cultivar is shifted to the later phases of seed maturation.

\section{References}

Baert, J., Van Laere, K., Ghesquiere, A., Aper, J.: Digestibility, forage and seed yield of two new Festulolium amphiploids. Grassland Sci. Eur. 24: 367-369, 2019.

Boelt, B., Studer, B.: Breeding for grass seed yield. - In: Boller, B., Posselt, U.K., Veronesi, F. (ed.): Fodder Crops and Amenity Grasses. Handbook of Plant Breeding Vol. 5. Pp. 161-174. Springer, Dordrecht 2010.

Černoch, V., Groenbaek, O.: Benefits of $\times$ Festulolium varieties in European agriculture. - Grassland Sci. Eur. 20: 386-388, 2015.

Coolbear, P., Hill, M.J., Win, P.: Maturation of grass and legume seed. - In: Fairey, D.T., Hampton, J.G. (ed.): Forage Seed Production. Vol. 1. Temperate species. Pp. 71-103. CABI, Walingford 1997.

Elgersma, A., Leeuwangh, J.E., Wilms, H.J.: Abscission and seed shattering in perennial ryegrass (Lolium perenne L.). Euphytica 39: 51-57, 1988.

Falkowski, M., Kozłowski, S., Kukułka, I.: [Development of generative shoots and seed yielding of grass plantations.] Biul. IHAR 199: 99-107, 1996. [In Pol.]

Ghesquière, M., Humphreys, M.W., Zwierzykowski, Z.: Festulolium. - In: Boller, B., Posselt, U.K., Veronesi, F. (ed.): Fodder Crops and Amenity Grasses. Handbook of Plant Breeding Vol. 5. Pp. 293-316. Springer, Dordrecht 2010.

Golińska, B.: [Investigations on seed retention strength in spikelets of Lolium multiflorum.] - Grassland Sci. Pol. 12: 37 46, 2009. [In Pol.]

Goliński, P.: [Investigations on tensile strength of plant material using a modern measuring stand.] - Grassland Sci. Pol. 12: 47-59, 2009. [In Pol.]

Goliński, P., Rzeźnik, A., Jokś, W., Golińska, B.: [Evaluation of growth regulators effect on seed yield of Festulolium braunii]. - Prog. Plant Prot. 50: 789-792, 2010. [In Pol.]

González-Carranza, Z.H., Lozoya-Gloria, E., Roberts, J.A.: Recent developments in abscission: shedding light on the shedding process. - Trends Plant Sci. 3: 10-14, 1998.

Humphreys, M., Marshall, A.: Herbage breeding and seed production: past, present and future. - In: Viiralt, R., Lillak, R. (ed.): Proceedings of the International Conference "Conventional and Ecological Grassland Management: Comparative Research and Development”. Pp. 46-52. Eesti Rohumaade Ühing, Tartu 2000.

Kryszak, J., Domański, P., Jokś, W.: Use of value of Festulolium braunii (K. Richter) A. Camus cultivars registered in Poland. - Grassland Sci. Eur. 7: 436-437, 2002.

Lorenzetti, F.: Achieving potential herbage seed yields in species of temperate regions. - In: Proceedings of the XVII International Grassland Congress. Pp. 1621-1628. New Zealand Grassland Association, Hamilton 1993.

Meier, U. (ed.): Growth stages of Mono-and Dicotyledonous Plants. BBCH Monograph. $2^{\text {nd }}$ Ed. - Federal Biological Research Centre for Agriculture and Forestry, Berlin Braunschweig 2001.

Olszewska, M.: [Productivity of Festulolium braunii (K. Richt.) A. Camus and Festuca pratensis L. grown in mixtures with Lotus corniculatus L. depending on multiple nitrogen rates.] Acta Sci. Pol. Agr. 7: 101-114, 2008. [In Pol.]

Opitz von Boberfeld, W., Banzhaf, K.: Yield and forage quality of different $\times$ Festulolium cultivars in winter. - J. Agron. Crop Sci. 192: 239-247, 2006.

Rolston, M.P., Chynoweth, R.J.: Harvest loss in ryegrass seed crops. - In: Smith, G.R., Evers, G.V., Nelson, L.R. (Ed.): Proceedings of the $7^{\text {th }}$ International Herbage Seed Conference. Pp. 64-68. International Herbage Seed Group, Dallas 2010.

Sexton, R., Roberts, J.A.: Cell biology of abscission. - Annu. Rev. Plant Physiol. 33: 133-162, 1982.

Wolski, K., Bartmański, A., Gawęcki, J.: [Effect of different 
methods of meadows renovation using Festulolium on botanical composition and yield of sward.] - Grassland Sci. Pol. 9: 254-251, 2006. [In Pol.]

Wyss, U., Frick, R.: The ensilability of different varieties of Festulolium. - Grassland Sci. Eur. 24: 209-211, 2019.
Zwierzykowski, Z., Tayyar, R., Brunell, M., Lukaszewski, A.J.: Genome recombination in intergenic hybrids between tetraploid Festuca pratensis and Lolium multiflorum. - J. Hered. 89: 324-328, 1998. 